\title{
COMPLEMENT-FIXING ANTIBODIES TO BEDSONIA ORGANISMS IN REITER'S SYNDROME AND ANKYLOSING SPONDYLITIS
}

\author{
BY \\ T. D. KINSELLA*, W. L. NORTON†, AND M. ZIFF \\ From the Department of Internal Medicine (Rheumatic Diseases Unit), \\ University of Texas Southwestern Medical School, Dallas, Texas, U.S.A.
}

The Bedsonia organisms, agents of the psittacosislymphogranuloma venereum-trachoma-inclusion conjunctivitis group, have been shown by serological techniques and by isolation to be the cause of a polyarthritis of sheep (Mendlowski and Segre, 1960; Storz, Shupe, Marriott, and Thornley, 1965; Norton and Storz, 1967). By similar methods, they have also been implicated in the pathogenesis of some human cases of non-specific urethritis (Jones, 1964; Pasieczny and Sommerville, 1966; Ford, 1967). In addition, several reports have suggested a relationship between these organisms and the pathogenesis of the urethritis and arthritis of Reiter's syndrome. By means of light microscopy, Siboulet and Galistin (1962) demonstrated intracellular inclusions, which were histologically compatible with Bedsonia inclusions, in the cells of the urethral exudate of three patients with Reiter's syndrome. Amor, Coste, and Delbarre (1965) demonstrated by light microscopy intracellular bodies compatible with Bedsonia inclusions in the urethral and synovial exudates of some patients with Reiter's syndrome and ankylosing spondylitis. By electron microscopy, Lévy, Ryckewaert, Silvestre, Kahn, and Mitrovic (1966) demonstrated intracellular inclusions, the ultrastructure of which was similar to that of other agents of the Bedsonia group, in the synovial fluid of a single case of the dysenteric form of Reiter's syndrome. Finally, Schachter, Barnes, Jones, Engleman, and Meyer (1966) reported positive complement-fixation tests in approximately 35 per cent. of sixteen patients with Reiter's syndrome and isolation of Bedsonia agents from the joints of four of eight patients with this condition.

The present study was undertaken to determine the incidence of Bedsonia infection, as judged by a

\footnotetext{
*Post-graduate Fellow, Canadian Arthritis and Rheumatism Society. †Present address: Department of Internal Medicine, University of Tennessee, Memphis, Tennessee.
}

serum complement-fixation test, in patients with Reiter's syndrome and ankylosing spondylitis.

\section{Patients}

\section{Material and Methods}

24 men with Reiter's syndrome and 46 with ankylosing spondylitis were compared with 168 men attending a venereal disease clinic, 47 attending an arthritis clinic, and 39 normal controls. The average age and the racial distribution was as is indicated in the Table. All patients were residents of the Dallas area, except for 44 of the 46 patients with spondylitis who were residents of Montreal, Canada.

Reiter's Syndrome.-All patients exhibited urethritis and arthritis at the time of onset of their disease. Seventeen also had conjunctivitis and/or keratodermia blennorrhagica. In two patients, serum was obtained during a chronic phase of the disease. In the remainder, it was obtained either during the acute phase of the initial episode or during an acute recurrence of the disease.

Ankylosing Spondylitis.-All patients fulfilled the diagnostic criteria proposed for this disease (Bennett and Burch, 1967). In addition, two exhibited severe psoriasis with a destructive peripheral arthropathy. The disease was active in all cases, in the majority for longer than 10 years. All were seen at intervals of 3 to 4 weeks over a period of 16 weeks and serial samples of serum obtained. Samples obtained during clinical exacerbations were employed in the current study.

Venereal Disease Patients.-All were attending the Dallas Venereal Diseases Clinic. Although it was not possible to determine an exact aetiological diagnosis in each case, at least 85 per cent. came to the clinic with the symptoms and signs of an acute urethritis which had developed after exposure to risk. Samples of serum employed in the current study were always drawn before the initiation of specific therapy for the urethritis.

Arthritis Clinic Patients.-All were attending the Arthritis Clinic of Parkland Memorial Hospital, Dallas, and were representative of the patient population to be found in a general arthritis clinic. Samples of serum 
employed in the current study were obtained on a random basis from patients attending the clinic, excluding those with the diagnoses of Reiter's syndrome and ankylosing spondylitis.

Normal Controls.-This group consisted principally of medical students and laboratory personnel chosen on a random basis.

\section{Complement-Fixation Test}

Tests were done by a micromethod (Sever, 1962), utilizing a group antigen derived from a strain of Bedsonia capable of producing polyarthritis in sheep (Norton and Storz, 1967). The antigen was prepared by the method of Storz and McKercher (1962) from an agent grown in this laboratory on infected yolk sacs of chick embryos.

\section{Results}

The range of complement-fixation titres against a group Bedsonia antigen in an apparently uninfected population, including normal individuals, patients attending an arthritis clinic, and patients with ankylosing spondylitis is shown in the Table. From this data, a titre of $1: 8$ or greater was defined as a positive test. There was close agreement in the overall incidence of positive tests in the normal controls and arthritis clinic group, namely, 8 per cent. in each case. In the patients with ankylosing spondylitis it was 0 per cent. In the patients with Reiter's syndrome, the incidence of positive tests was 37 per cent. and in the V.D. clinic patients, 36 per cent.

\section{Discussion}

With the exception of the group of patients with ankylosing spondylitis, for whom no comparable data are available, the results of the present study are in agreement with previous studies of similar subjects, utilizing group antigens derived from various human strains of Bedsonia organisms. For example, Pasieczny and Sommerville (1966), employing the LB4 strain of TRIC agent, found an overall incidence of positive complement-fixation tests in 53 per cent. of a large group of patients with a variety of venereal diseases. The incidence of positive tests was 15.5 per cent. in normal control subjects. Dunlop, Harper, Al-Hussaini, Garland, Treharne, Wright, and Jones (1966), employing an antigen from a strain of lymphogranuloma venereum agent, found positive tests in three of six patients with non-specific urethritis. Schachter and others (1966), employing the 6BC strain of psittacosis agent, found positive tests in approximately 35 per cent. of patients with Reiter's syndrome and in 2 per cent. of a group of control patients derived from an arthritis clinic. Thus, as might be expected, the use in the present study of a group antigen derived from a sheep strain of Bedsonia does not seem to have had a significant influence on the results.

It is clear from the present results that there was an increased percentage of positive tests in both the V.D. clinic patients and those with Reiter's syndrome. Furthermore, when these two groups are compared, the results are virtually identical -36 and 37 per cent. positive, respectively.

The comparable frequency of complement-fixing antibodies to the group antigen of Bedsonia in patients with Reiter's syndrome and in those with venereal urethritis without Reiter's syndrome might be explained in several ways:

(1) Since the test antigen employed is groupspecific, it may not be possible to differentiate between a strain which might be responsible for Reiter's syndrome and other strains which are $\frac{\Phi}{2}$ responsible for other venereal syndromes.

(2) A single agent might be responsible for the serological findings in both groups, and this agent may be capable, under certain circumstances, of

TABLE

DISTRIBUTION OF PATIENTS BY AGE, RACE, AND COMPLEMENTFIXATION TITRES AGAINST BEDSONIA ANTIGEN

\begin{tabular}{|c|c|c|c|c|c|c|c|c|c|c|}
\hline \multirow{2}{*}{ Patient Group } & \multirow{2}{*}{$\begin{array}{c}\text { No. } \\
\text { of } \\
\text { Cases }\end{array}$} & \multirow{2}{*}{$\begin{array}{c}\text { Average } \\
\text { Age } \\
\text { (yrs) }\end{array}$} & \multicolumn{2}{|c|}{ Racial Distribution } & \multicolumn{4}{|c|}{ Reciprocal Titre } & \multicolumn{2}{|c|}{ Positive* Tests } \\
\hline & & & White & Negro & 0 & 4 & 8 & $\geqslant 16$ & No. & Per cent. \\
\hline Reiter's Syndrome & 24 & $30 \cdot 1$ & 17 & 7 & 15 & 0 & 6 & 3 & 9 & 37 \\
\hline V.D. clinic & 168 & $33 \cdot 3$ & 21 & 147 & 80 & 27 & 36 & 25 & 61 & 36 \\
\hline Ankylosing Spondylitis & 46 & 46 & 46 & $\mathbf{0}$ & 44 & 2 & 0 & 0 & 0 & $\mathbf{0}$ \\
\hline Arthritis clinic & 47 & $45 \cdot 7$ & 31 & 16 & 40 & 3 & 1 & 3 & 4 & 8 \\
\hline Normal controls & 39 & $27 \cdot 6$ & 35 & 4 & 34 & 2 & 2 & 1 & 3 & 8 \\
\hline
\end{tabular}

*A titre of 1:8 or greater was defined as positive. 
producing Reiter's syndrome. If it is postulated that all cases of Reiter's syndrome are caused by such an agent, it is surprising that a higher incidence of positive tests was not found in the Reiter's group.

(3) Bedsonia infection may be frequently associated with venereal infections of various types, but such infection may not be related to the actual pathogenesis of Reiter's syndrome.

The relatively low incidence of a demonstrable antibody response to the Bedsoniae in patients with Reiter's syndrome, i.e. less than $\mathbf{4 0}$ per cent., is not necessarily incompatible with an aetiological role for the Bedsoniae in this disease. A comparatively low incidence of complement-fixing antibody has been found in the naturally-occurring sheep polyarthritis caused by a Bedsonia agent (Storz, Shupe, James, and Smart, 1963). Thus, the data reported here do not resolve the role of Bedsonia infection in Reiter's syndrome, but rather emphasize the difficulties previously noted by Schachter and others (1966) in establishing this relationship.

In view of the well-recognized clinical and radiological similarities between Reiter's syndrome and ankylosing spondylitis (Mason, Murray, Oates, and Young, 1958; Good, 1965), the failure to detect anti-Bedsonia antibodies in the sera of the present group of spondylitis patients is of interest. In only two patients was any antibody detected, and in these it was present in low titre. In ten patients, simultaneous tests were done on specimens collected 1 to
3 months apart and no positive results were obtained. Since it is possible that there may be significant geographical variations in the distribution of the Bedsoniae (Horsfall and Tamm, 1965), it should be noted in the interpretation of these data that 44 of the 46 spondylitis patients were not residents of the Dallas area. Nevertheless, since all of these patients were known to have active disease, it would appear that there was no serological evidence that active Bedsonia infection was involved in the pathogenesis of their spondylitis.

\section{Summary}

Employing a group-specific antigen, serum complement-fixing antibody titres to the Bedsonia organism were determined in patients with Reiter's syndrome and ankylosing spondylitis, in a venereal disease clinic population, and also in control groups of normal individuals and patients attending an arthritis clinic. There was a comparably increased frequency of positive tests in patients with Reiter's syndrome and patients attending the venereal disease clinic. Single and serial sera from patients with ankylosing spondylitis showed no evidence of antibody. The significance of these results is discussed.

The authors express their appreciation to Dr. Lee Alexander of the Dallas Public Health Clinic for his generous cooperation.

\section{REFERENCES}

Amor, B., Coste, F., and Delbarre, F. (1965). Presse méd., 73, 1825 (Sur l'origine virale possible du syndrome oculo-uréthro-synovial).

Bennett, P. H., and Burch, T. A. (1967). Bull. rheum. Dis., 17, 453 (New York symposium on population studies in the rheumatic diseases: new diagnostic criteria).

Dunlop, E. M. C., Harper, I. A., Al-Hussaini, M. K., Garland, J. A., Treharne, J. D., Wright, D. J. M., and Jones, B. R. (1966). Brit.J. vener. Dis., 42, 77 (Relation of TRIC agent to "non-specific" genital infection).

Ford, D. K. (1967). "Proceedings IV Panamerican Congress of Rheumatology, Mexico City, 1967" (The etiology of non-gonococcal urethritis and Reiter's syndrome). Exc. med. int. Congr. Ser., No. 143, p. I 71, Abstr. no. 131.

Good, A. E. (1965). Acta rheum scand., 11, 305 (Reiter's disease and ankylosing spondylitis).

Horsfall, F. L., and Tamm, I. (1965). "Viral and Rickettsial Infections of Man", 4th ed., p. 1031. Lippincott, Philadelphia.

Jones, B. R. (1964). Brit. J. vener. Dis., 40, 3 (Ocular syndromes of TRIC virus infection and their possible genital significance).

Lévy, J. P., Ryckewaert, D., Silvestre, D., Kahn, M. F., and Mitrovic, D. (1966). Path. et Biol., 14, 216 (Étude par microscopie électronique des inclusions des cellules synoviales dans un cas de syndrome oculo-uréthro-synovial).

Mason, R. M., Murray, R. S., Oates, J. K., and Young, A. C. (1958). Brit. med.J., 1, 748 (Prostatitis and ankylosing spondylitis).

Mendlowski, B., and Segre, D. (1960). Amer. J. vet. Res., 21, 68 (Polyarthritis in sheep, I. Description of the disease and experimental transmission).

Norton, W. L., and Storz, J. (1967). Arthr. and Rheum., 10, 1 (Observations on sheep with polyarthritis produced by an agent of the psittacosis-lymphogranuloma venereum-trachoma group). 
Pasieczny, T., and Sommerville, R. G. (1966). Brit.J. vener. Dis., 42, 191 (Outbreak of non-specific urethritis associated with the presence of complement-fixing antibodies to the LB4 strain of TRIC agent).

Schachter, J., Barnes, M. G., Jones, J. P., Engleman, E. P., and Meyer, K. F. (1966). Proc. Soc. exp. Biol. (N. Y.), 122, 283 (Isolation of Bedsoniae from the joints of patients with Reiter's syndrome).

Sever, J. L. (1962). J. Immunol., 88, 320 (Application of a microtechnique to viral serological investigations).

Siboulet, A., and Galistin, P. (1962). Brit. J. vener. Dis., 38, 209 (Arguments in favour of a virus aetiology of non-gonococcal urethritis illustrated by three cases of Reiter's disease).

Storz, J., and McKercher, D. G. (1962). Zbl. Vet.-med., 9, 411 (Etiological studies on epizootic bovine abortion).

- Shupe, J. L., James, L. F., and Smart, R. A. (1963). Amer. J. vet. Res., 24, 1201 (Polyarthritis of sheep in the intermountain region caused by a psittacosis-lympho-granuloma agent).

,-- Marriott, M. E., and Thornley, W. R. (1965). J. infect. Dis., 115, 9 (Polyarthritis of lambs induced experimentally by a psittacosis agent).

Les anticorps fixateurs de complément vis à vis du microorganisme Bedsonia dans le syndrome de Reiter et la spondylarthrite ankylosante

RÉsumé

A l'aide d'un antigène spécifique on a déterminé dans le sérum le titre de l'anticorps fixateur de complément vis à vis de l'organisme Bedsonia chez des malades ayant un syndrome de Reiter et une spondylarthrite ankylosante, chez des sujets consultant dans un dispensaire pour maladies vénériennes ainsi que chez des témoins normaux et des sujets consultant dans un service de rhumatologie. On a trouvé une fréquence de tests positifs comparativement plus grande chez les malades atteints de syndrome de Reiter ainsi que chez les sujets consultant dans un dispensaire pour maladies vénériennes. Chez les malades ayant une spondylarthrite ankylosante on n'a pas mis en évidence d'anticorps, que le prélèvement ait été unique ou répété. On discute la portée de ces résultats.
Anticuerpos de fijación de complemento específicos de los $\AA$ organismos Bedsonia en el síndrome de Reiter y la espondi- $\overrightarrow{0}$ lartritis anquilosante

Sumario

Empleando un antígeno específico se determinó en el suero el título del anticuerpo de fijación de complementopara el micro-organismo Bedsonia en enfermos con $\overrightarrow{0}$ síndrome de Reiter y con espondilartritis anquilosante, $\infty$ en sujetos que frecuentaron una clínica de enfermedades venéreas así como en sujetos normales y en personas queo frecuentaron una clínica reumatológica. La frecuencia de las reacciones positivas fué comparativamente mayor en enfermos con síndrome de Reiter y en sujetos queô frecuentaron la clínica de vereología. Sueros recogidos $\frac{}{\mathbb{Q}}$ uno o más veces en enfermos con espondilartritis anquilo-@ sante no evidenciaron existencia del anticuerpo buscado. $\overrightarrow{\vec{A}}$ Se discute la importancia de estos resultados. 